\title{
THE SIGNIFICANCE OF THE D:N RATIO AND ITS BEARING ON THE MECHANISM OF DIABETES MELLITUS
}

\author{
BY D. R. DRURY \\ With THE tech Nical AsSistance of HAROLD EDELBROCK ANd LEE MILL \\ (From the Department of Physiology, School of Medicine, University of Southern California, \\ Los Angeles)
}

(Received for publication August 18, 1941)

The $D: N$ ratio plays a very important part in establishing our present day tenets of intermediary metabolism and it does so particularly in that part of metabolism dealing with the theory of diabetes. At the present time there exists no satisfactory basic theory accounting for the disturbance of metabolism in this disease. One has but to note the extreme divergence of viewpoint of accepted authorities in this field to be aware of this. On the one hand, there are those (1) who state that the diabetic organism can burn glucose as readily as the normal and that the trouble results entirely from the over-production of sugar from non-carbohydrate sources. Opposed to these we have an equally authoritative group (2) who claim that diabetes results simply from the inability of the organism to burn glucose. Much of the divergence of opinion is due to differences in the interpretation of the $D: N$ ratio and of the $D:$ Protein ratio. ${ }^{1}$

The general belief that but 58 per cent of protein can be converted to glucose in the body rests on the observation that the $D: N$ ratio of the fasting phlorhizinized $\operatorname{dog}$ is $3.65^{2}$ (3). The claim that the completely diabetic animal cannot utilize glucose rests on the fact that the $D: N$ ratio in this condition approaches this value of 3.65. It is apparent, then, that any error in this basic value should be corrected. The fasting phlorhizinized dog excretes 3.65 grams glucose for each gram of $\mathrm{N}$ in the urine and, since one gram of $\mathrm{N}$ would come from 6.25 grams protein, it has been concluded that 3.65 grams of glucose is the maximal amount that can be converted from this amount of protein. However, this concept requires that all the glucose so formed in the phlorhizinized animal is excreted and that none is burned by the tissues. Workers responsible for

$1 \mathrm{D}:$ Protein ratio $=\mathrm{D}: \mathrm{N} \times 6.25$.

2 Or a D : Protein ratio of $3.65 / 6.25=0.58$. this view have completely ignored this possibility (4) but it remains nonetheless a necessary postulate of their contention.

On the contrary, there is much to support the view that the tissues of these animals do use a certain amount of glucose. Deuel et al. (5) and Wierzuchowski (6) have examined this question by administering sugar to fasting phlorhizinized dogs. After the administration of the sugar they obtained a rise in the respiratory quotient which they interpreted as evidence of increased oxidation of carbohydrate. Since the tissues of this preparation are capable of oxidizing glucose given by mouth, it is quite possible that they can oxidize glucose that has its origin from body protein. The fate of glucose arising from protein fed to these animals would give a clue to this. Lusk states (3) that, if meat be fed to the phlorhizinized fasting dog, the urine sugar and nitrogen increase but that the $D: N$ ratio is unchanged. Examination of the protocols of the original reports from Lusk's laboratory (4) shows that usually small amounts of protein were fed so that the nitrogen excretion was increased very little. The effects on excretion of the administered protein, then, would be largely masked by the large basic excretion resulting from the body protein breakdown. Despite this, in several of their experiments the dogs showed a drop in the $D: N$ ratio when protein was fed. Janney and Blatherwick (7) also fed amounts of protein that were small when compared to the basic body protein catabolism. The animals showed slight drops in the $D: N$ ratio as a result of the protein feeding. More recently, Gray et al. (8) found some drop in $\mathrm{D}: \mathrm{N}$ ratio. with feeding protein and here again the increase in nitrogen metabolized for the fed period over the fasting period was very small. It is obvious that, if one wished to determine the effect of fed protein on the $D: N$ ratio of the 
phlorhizinized dog, he should feed enough of it at least to double the fasting nitrogen excretion. Since in past experiments this has usually not been the case, such an investigation was undertaken and is reported here.

\section{EXPERIMENTAL}

The experiments were carried out on three dogs. Two of the animals were subjected to a control period of 4 or 5 days fasting with the daily injection of $1 \mathrm{gram}$ of phlorhizin suspended in olive oil. The feeding period was then instituted during which time the phlorhizin was continued and the animal was fed amounts of meat or

TABLE I

The effect of protein feeding on sugar excretion of phlorhizinized dog

(1 gram phlorhizin from July 13 on; no food July 10 to 13)

\begin{tabular}{c|c|c|c|c|c}
\hline Date & Food & $\begin{array}{c}\text { Urine } \\
\text { sugar }\end{array}$ & $\begin{array}{c}\text { Urine } \\
\text { nitrogen }\end{array}$ & $\begin{array}{c}\text { Urinary } \\
\text { D : N } \\
\text { ratio }\end{array}$ & $\begin{array}{c}\text { Body } \\
\text { weight }\end{array}$ \\
\cline { 2 - 4 } July & grams & grams & grams & & lbs. \\
14 & 0 & 18.9 & 5.7 & 3.32 & \\
15 & 0 & 30.0 & 8.7 & 3.45 & \\
16 & 0 & 22.6 & 6.65 & 3.4 & 25 \\
17 & 1300 meat & 71.5 & 28.8 & 2.48 & 24.5 \\
18 & 1300 meat & & 31.6 & & \\
19 & 1320 meat & 84.0 & 34.0 & 2.47 & 27.5 \\
20 & 1350 meat & 94.5 & 36.8 & 2.56 & \\
21 & 900 meat & 95.0 & 33.8 & 2.70 & 28.5 \\
22 & 0 & 51.2 & 12.0 & 4.27 & \\
23 & 0 & 30.7 & 7.7 & 3.98 & \\
24 & 0 & 28.9 & 7.35 & 3.93 & 23.75 \\
25 & 0 & 24.1 & 6.4 & 3.77 & 22.75 \\
\hline
\end{tabular}

TABLE II

The effect of protein feeding on sugar excretion of phlorhizinized dog

(1 gram phlorhizin daily from June 20 on; 450 grams meat daily June 21 to 25 )

\begin{tabular}{|c|c|c|c|c|c|}
\hline Date & Food & $\begin{array}{l}\text { Urine } \\
\text { sugar }\end{array}$ & $\begin{array}{c}\text { Urine } \\
\text { nitrogen }\end{array}$ & $\begin{array}{l}\text { Urinary } \\
\mathbf{D}: \mathbf{N} \\
\text { ratio }\end{array}$ & $\begin{array}{l}\text { Body } \\
\text { weight }\end{array}$ \\
\hline Iune & & grams & grams & & lbs. \\
\hline $\begin{array}{l}26 \\
27 \\
28 \\
29 \\
30\end{array}$ & $\begin{array}{c}900 \text { meat } \\
860 \text { meat } \\
920 \text { meat } \\
920 \text { meat } \\
0\end{array}$ & $\begin{array}{l}60.5 \\
48.5 \\
91.5 \\
81.3 \\
38.1\end{array}$ & $\begin{array}{r}23.1 \\
15.5 \\
30.9 \\
26.9 \\
8.8\end{array}$ & $\begin{array}{l}2.61 \\
3.13 \\
2.96 \\
3.02 \\
4.33\end{array}$ & $\begin{array}{l}28.75 \\
28.5 \\
28.75 \\
28.5 \\
27.5\end{array}$ \\
\hline $\begin{array}{c}\text { July } \\
1 \\
2 \\
3 \\
4 \\
5 \\
6 \\
7 \\
8\end{array}$ & $\begin{array}{c}0 \\
0 \\
840 \text { meat } \\
840 \text { meat } \\
920 \text { meat } \\
450 \text { meat } \\
0 \\
0\end{array}$ & $\begin{array}{l}35.0 \\
22.0 \\
70.5 \\
73.0 \\
78.0 \\
70.5 \\
34.0 \\
31.5\end{array}$ & $\begin{array}{c}.9 .85 \\
6.8 \\
27.3 \\
26.7 \\
26.6 \\
22.4 \\
7.2 \\
9.0\end{array}$ & $\begin{array}{l}3.56 \\
3.24 \\
2.59 \\
2.73 \\
2.93 \\
3.15 \\
4.70 \\
3.5\end{array}$ & $\begin{array}{l}27.0 \\
25.5 \\
27.0 \\
26.75 \\
26.75 \\
27.25\end{array}$ \\
\hline
\end{tabular}

TABLE III

The effect of protein feeding on sugar excretion of phlorhizinized dog

(1 gram phlorhizin daily from May 15 on; no food May 15 to 17)

\begin{tabular}{|c|c|c|c|c|c|}
\hline Date & Food & $\begin{array}{l}\text { Urine } \\
\text { sugar }\end{array}$ & $\begin{array}{c}\text { Urine } \\
\text { nitro- } \\
\text { gen }\end{array}$ & $\mid \begin{array}{c}\text { Urinary } \\
\mathbf{D}: \mathbf{N} \\
\text { ratio }\end{array}$ & $\begin{array}{c}\text { Body } \\
\text { weight }\end{array}$ \\
\hline $\begin{array}{c}\text { May } \\
18 \\
19 \\
20 \\
21 \\
22 \\
23\end{array}$ & $\begin{array}{c}0 \\
0 \\
\text { *Amino acids } 550 \mathrm{cc} . \\
\text { *Amino acids } 550 \mathrm{cc} \text {. } \\
\text { Meat } 500 \text { grams } \\
\text { Meat } 500 \text { grams }\end{array}$ & $\begin{array}{l}\text { grams } \\
23.2 \\
20.0 \\
30.0 \\
15.95 \\
30.5 \\
43.4\end{array}$ & $\begin{array}{c}\text { grams } \\
6.46 \\
6.08 \\
11.9 \\
10.5 \\
18.5 \\
33.0\end{array}$ & $\begin{array}{l}3.60 \\
3.28 \\
2.52 \\
1.52 \\
1.64 \\
1.31\end{array}$ & $\begin{array}{l} \\
19.5 \\
20.0\end{array}$ \\
\hline
\end{tabular}

* A solution of amino acids prepared by hydrolysis of casein containing 1 per cent nitrogen. This product was supplied by Frederick Stearn and Company Laboratory.

amino acids sufficient to give a definite increase in urinary nitrogen. In the other animal the fasting control period was interposed between two feeding periods. The urine sugars for Dogs 1 and 2 were determined by Benedict's method and for Dog 3 by that of Shaffer and Hartmann. Nitrogens were determined by the Kjeldahl method. The meat was usually fed in two portions, at 9 a.m. and at 5 p.m. The results are given in Tables I to III.

\section{DISCUSSION}

It is apparent that there is always a drop in the $D: N$ ratio when protein is fed. The average for the fasting periods is 3.50 (not including the first 2 days after food is stopped) and for the feeding periods, 2.40. This brings up the question: if the animal is making 3.5 grams of sugar for each gram body protein nitrogen metabolized when fasting, why does he produce but 2.4 grams sugar when 1 gram of food protein nitrogen is metabolized? The most probable explanation would appear to be that he makes as much sugar from food protein as from body protein but that a certain portion of the glucose that is manufactured by the liver is utilized by the other tissues. Certainly the reactions of the dogs themselves support this view. After 4 or 5 days of fasting and phlorhizin the dogs are usually weak and listless. The eating of the protein results in marked improvement in strength and activity, which is similar to the effect of giving glucose to such an animal and indicates an increased utilization of glucose. Bollman, Mann and Magath (9) have shown that the liver is the site of transformation of amino acids to glucose. This obtains for 
amino acids either derived from food or body protein. The liver adds this new formed glucose to the general blood stream. From the blood stream the extra hepatic tissues receive glucose which may have had its origin in food carbohydrate, in body glycogen, or in body or food protein that has been changed in the liver. These tissues could in no way discriminate between glucose molecules of these different origins and, since they utilize glucose that has come from food sources, there is every likelihood that they utilize glucose which has arisen from body protein. And yet such a discrimination by the tissues would have to be postulated if we accept the statement that only 3.7 grams of glucose can come from the protein which gives 1 gram of urinary nitrogen.

The idea that the tissues of the phlorhizinized animal use no glucose appears conjectural and is without adequate experimental support. It is true that the amounts of glucose used are relatively small (10) but this low rate is probably the result of fasting rather than any specific effect of phlorhizin. Bergman and Drury (11) have shown that a fast of 3 to 4 days diminishes markedly the utilization of glucose by the extra hepatic tissues. The phenomenon of "starvation diabetes" first described by Hofmeister (12) could also play a rôle here. It is well known today that, if sugar is given to an animal that has been fasting for some time, very little of it is utilized (13). Furthermore, these animals always show a low blood sugar level and it is possible that the hypoglycemia itself may lower the rate of glucose utilization. There is, then, adequate experimental explanations for the low glucose utilization rate of the tissues of the fasting phlorhizinized dog without having recourse to the conjecture that phlorhizin itself prevents glucose oxidation completely. When the phlorhizinized animal is fed, as our results show, his tissues begin again to use more glucose.

\section{EXPERIMENTS ON DEPANCREATIZED DOGS}

The depancreatized animal has also been used for the purpose of determining the protein-tosugar ratio. In the past it was assumed that the tissues of this preparation used no glucose. In the light of recent work this assumption can no longer be maintained. When the liver of the dia- betic animal is removed, the blood sugar falls and glucose must be administered to keep the animal from becoming hypoglycemic. The brain of the diabetic animal utilizes glucose almost exclusively and its cells die if they do not have this substance to burn (14). The resting muscle of the diabetic uses glucose (15). We have here evidence that at least two tissues of the body use glucose at all times. It is obvious that any attempt to evaluate the $\mathrm{D}: \mathrm{N}$ ratio of the depancreatized animal must include an estimation of the glucose utilized by the tissues in addition to that which is excreted.

To this end the following experiments were carried out:

After pancreatectomy dogs were kept on food and insulin for about one month in order to have good healing and recovery. They were then carried for the experimental period which consisted essentially of determining the amount of glucose excreted as a result of protein feeding. Control periods were run for the purpose of correcting for the sugar utilization of the tissues. This was done by determining the amount of sugar that had to be fed to give the same amount of glycosuria. For the experimental periods of our first animals we withheld insulin completely, but this resulted in an unsatisfactory condition of the dogs when fed meat. They developed marked ketosis, vomited and lost desire for food. Two of these animals died. We found that a small daily dose of protamine insulin kept the dogs in excellent condition and with good appetites, without lowering the glycosuria to any great extent. All urine sugars were done by the method of Shaffer and Hartmann. The first dog studied was given 700 grams of lean meat daily for 8 days, then 100 grams sugar daily for 3 days and finally 850 grams meat daily for 8 days. Five units of protamine insulin

TABLE IV

Comparison of effect of sugar and protein feeding on sugar excretion of depancreatized dog

\begin{tabular}{c|c|c|c|c|c}
\hline \hline $\begin{array}{c}\text { Food per } \\
\text { day }\end{array}$ & $\begin{array}{c}\text { Number } \\
\text { of days }\end{array}$ & $\begin{array}{c}\text { Insulin } \\
\text { units } \$ \\
\text { per day }\end{array}$ & $\begin{array}{c}\text { Urine } \\
\text { sugar }\end{array}$ & $\begin{array}{c}\text { Urine } \\
\text { nitrogen }\end{array}$ & $\begin{array}{c}\text { Urinary } \\
\text { D: }: N \\
\text { ratio }\end{array}$ \\
\hline grams & & & $\begin{array}{c}\text { grams per } \\
\text { day }\end{array}$ & $\begin{array}{c}\text { grams per } \\
\text { day }\end{array}$ & \\
700 meat. & 8 & 5 & $\begin{array}{c}37.8 \\
17.2\end{array}$ & 2.2 \\
100 sugar. & 3 & 5 & 49.0 & 2.3 & 2.3 \\
850 meat. & 8 & 5 & 66.0 & 22.8 & 2.9 \\
\hline
\end{tabular}


per day were given throughout. The averages for the three periods are given in Table IV. The results of the first day of each period are not included in the averages because of the well-known delay in attaining a steady state when one changes from a high to a low protein intake or vice versa (16). In the second period the tissues must have used 51 grams of sugar daily plus a small amount which might have resulted from the catabolism of the protein represented by 2.3 grams of urinary nitrogen. In the protein feeding periods the tissues must have utilized about the same daily amount of glucose (probably a little less in the first period and a little more in the third) since the average blood sugar levels must have been about the same as during the second period in order to give the same average glycosuria. The averages for the first and third periods are: urine sugar 51.6 grams and urine nitrogen 20.0 grams. We can assume, then, that the protein that gave 20 grams urinary nitrogen gave rise to as much glucose as did the 100 grams fed sugar plus the protein that gave 2.3 grams urinary nitrogen in the second period. In order to get the ratio between sugar and nitrogen we may say : 20 grams protein $\mathrm{N}$ is equivalent to 100 grams sugar plus 2.3 grams protein $\mathrm{N}$.

Subtracting 2.3 grams protein $\mathrm{N}$ from both sides, we obtain 17.7 grams protein $\mathrm{N}$ which is equivalent to 100 grams sugar. This correction for the nitrogen excreted during the sugar feeding period must be made regardless of the view one may have as to what it represents in actual metabolism. If it represents body protein catabolized to form sugar, then there was that much additional sugar produced in that period. If it results from metabolic processes not giving rise to sugar, then we must assume that the same processes operated during the first and third periods, giving rise to the same amount of urinary nitrogen which did not contribute to the glucose produced. This portion should be subtracted from that connected with the sugar formation. We believe that both factors probably operate to produce this nitrogen in the sugar feeding period. These calculations give us the conclusion that 17.7 grams protein nitrogen is equivalent to 100 grams sugar. This is a $\mathrm{D}: \mathrm{N}$ ratio of 5.65 or a $\mathrm{D}:$ Protein ratio of 0.90 .
A similar experiment was carried out on another depancreatized dog and the results are given in Table V. The calculations for this experiment are not as simple as in the first case since even on the higher meat intake he did not excrete as much

TABLE $V$

Comparison of effect of sugar and protein feeding on sugar excretion of depancreatized dog

\begin{tabular}{c|c|c|c|c|c}
\hline $\begin{array}{c}\text { Food per } \\
\text { day }\end{array}$ & $\begin{array}{c}\text { Number } \\
\text { of days }\end{array}$ & $\begin{array}{c}\text { Insulin } \\
\text { units } \\
\text { per day }\end{array}$ & $\begin{array}{c}\text { Urine } \\
\text { sugar }\end{array}$ & $\begin{array}{c}\text { Urine } \\
\text { nitrogen }\end{array}$ & $\begin{array}{c}\text { Urinary } \\
\mathbf{D}: \mathbf{N} \\
\text { ratio }\end{array}$ \\
\hline grams & & & $\begin{array}{c}\text { grams per } \\
\text { day }\end{array}$ & $\begin{array}{c}\text { grams per } \\
\text { day }\end{array}$ & \\
50 sugar. & 5 & 3 & 46.3 & 1.76 & \\
200 meat. & 4 & 3 & 23.8 & 5.59 & 4.25 \\
400 meat. & 2 & 3 & 38.7 & 10.8 & 3.58 \\
\hline
\end{tabular}

glucose as during the sugar feeding period. However, on the sugar regime the tissues utilized $\mathbf{5 0}$ - 46.3 or 3.7 grams sugar plus what was produced in the processes, giving rise to 1.76 grams nitrogen. On the high meat regime (400 grams meat) we can assume that the tissues utilized close to this amount: let us say 3 grams plus the same amount connected with the 1.76 grams nitrogen. If, then, as before, we subtract the 1.76 grams $\mathrm{N}$ of the control period from 10.8 grams $\mathrm{N}$ of the protein period, we obtain 9.04 grams $\mathrm{N}$ which is equivalent to ( 38.7 plus 3 ) grams sugar and which gives us an actual D:N ratio of 4.6. The results for the lower meat intake period (200 grams meat) may be similarly treated except that here we must assume that even less sugar was used by the tissues. However, even if we do not add anything to the urine sugar for this correction, we obtain $(5.59-1.76)$ grams nitrogen which is equivalent to 23.8 grams sugar or a $\mathrm{D}: \mathrm{N}$ ratio of 6.2 or a $\mathrm{D}:$ Protein ratio close to 1 .

Two other experiments were carried out in this way with diabetic dogs. In these, fat-free meat was fed in place of ordinary lean meat. This was done in order to avoid any possible effect that even the small amount of fat in lean meat may have had. There is little likelihood of this since fat fed to diabetic dogs does not increase their sugar excretion. The meat was treated with alcohol, dried and powdered, then extracted with petroleum ether and finally with diethyl oxide. The results are given in Table VI. The levels of glycosuria are lower for the protein regime than 
TABLE VI

Comparison of effect of sugar and protein feeding on sugar excretion of depancreatized dog

(Dog 6)

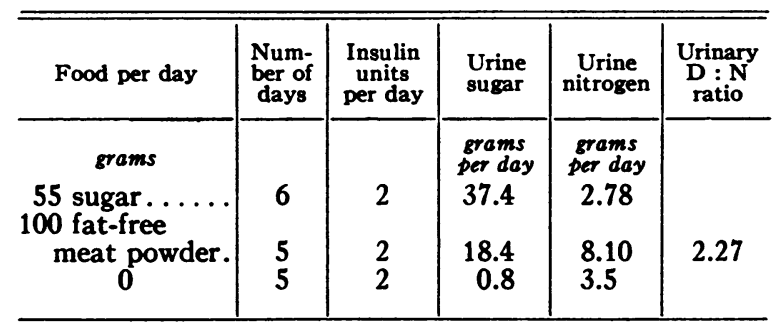

(Dog 7)

\begin{tabular}{c|c|c|c|c|c}
\hline $\begin{array}{l}\text { 43 sugar...... } \\
\text { 80 fat-free }\end{array}$ & 7 & 3 & 37.2 & 1.77 & \\
meat powder. & 5 & 3 & 22.0 & 5.96 & 3.7 \\
0 & 5 & 3 & 6.06 & 2.57 & \\
\hline
\end{tabular}

for that with sugar feeding due to the fact that the dogs did not absorb the meat powder as well as expected. However, judging from the glycosurias of the different regimes, the tissue utilization during the meat feeding period should have been approximately the mean of those of the sugar feeding and of the fasting periods. The tissues of Dog 6 during the sugar feeding period utilized 17.6 grams sugar in addition to that which came from the protein catabolized, and during the fasting period utilized the sugar coming from the protein minus the sugar excreted ( 0.8 gram). The average of these is 8.3 grams sugar plus 3.14 grams nitrogen. The calculation for the sugar-nitrogen equivalent of the meat period would then be (18.4 plus 8.3 ) grams sugar which is equivalent to $(8.10-3.14)$ grams nitrogen, or an actual $\mathrm{D}: \mathrm{N}$ ratio of 5.38. The calculation for Dog 7 would be similar $(22-0.13)$ grams sugar which is equivalent to $(5.96-2.17)$ grams nitrogen or an actual $\mathrm{D}: \mathrm{N}$ ratio of 5.78 .

\section{DISCUSSION}

The experimental results given in this paper indicate that the conventional interpretation of the $\mathrm{D}: \mathrm{N}$ ratio in metabolism and dietetics should be changed. To the urinary sugar excreted by the fasting phlorhizinized dog must be added an amount equal to that which is utilized by the tissues in order to derive the sugar equivalent of protein from the urinary $D: N$ ratio. Our findings show that one is not justified in deducing this equivalent from the extra sugar excreted by phlorhizinized dogs after being fed protein, since this feeding increases the tissue utilization of glucose. In the fasting phlorhizinized dog the glucose utilization rate of the tissues is $75 \mathrm{mgm}$. per kilo per hour (10). When this amount is added to that which is excreted in the urine, we obtain a $D: N$ ratio of 6 instead of the conventional 3.65, and a $\mathrm{D}:$ Protein ratio close to 1 .

Similarly, the tissues of the fasting depancreatized animal utilize sugar (17) and a similar correction should be made here if one wishes to derive the protein-sugar equivalent from observations on this preparation. There is some increase in utilization on feeding glucose (18) but it does not increase as markedly with feeding as in the case of the phlorhizinized fed dog. This is apparent from the fact that the urinary $D: N$ ratios of almost all our protein-fed depancreatized dogs were higher than the usual 2.7 ratio for fasting, and this despite some insulin given to our animals. This fact has made it possible for us to determine the protein-sugar equivalent from our protein-fed depancreatized dogs since here tissue utilization is relatively small and can be corrected for by control periods of sugar feeding. When this is done we find that the true $D: N$ ratio is between 5 and 6.

The highest urinary $D: N$ ratio obtained for fasting depancreatized dogs is 2.7. Even severe diabetic patients rarely show as high ratios as this. The difference between the values for this ratio and that for the true ratio indicates that there is ample glucose available from that converted from body protein to take care of the tissue needs in the fasting diabetic. This can be seen from the following calculations. The normal fasting dog excretes $10.8 \mathrm{mgm}$. $\mathrm{N}$ per kilo per hour (19). If we accept the true $D: N$ ratio as 5.50 , this would indicate a tissue utilization of glucose by this animal of $60 \mathrm{mgm}$. per kilo per hour. Fasting man excretes $7.6 \mathrm{mgm}$. per kilo per hour (20); which would indicate a tissue utilization of 42 mgm. per kilo per hour. The fasting phlorhizinized dog (4th to 6th day of fasting) excretes $37.5 \mathrm{mgm}$. $\mathrm{N}$ and $136 \mathrm{mgm}$. glucose per kilo per hour (4). This nitrogen would be equivalent to $37.5 \times 5.5 \mathrm{mgm}$. or $207 \mathrm{mgm}$. glucose. Subtracting from this the glucose excreted in the urine, 
we obtain a tissue utilization of $70 \mathrm{mgm}$. per kilo per hour. The fasting depancreatized dog (3rd to 6 th day of fasting) excretes $22.3 \mathrm{mgm}$. $\mathrm{N}$ and 65 mgm. glucose per kilo per hour (21). The tissue utilization here would be $(22.3 \times 5.5)$ minus 65 , or $58 \mathrm{mgm}$. glucose per kilo per hour. A very severe case of human diabetes (3rd to 5 th day fasting) excreted $19.8 \mathrm{mgm}$. $\mathrm{N}$ and $55 \mathrm{mgm}$. glucose per kilo per hour (22). This would indicate a tissue utilization of $(19.8 \times 5.5)$ minus 55 , or 54 mgm. glucose per kilo per hour. All experimental work leads us to expect about the same tissue utilization for these different conditions (17). If protein is the only non-carbohydrate source of glucose this utilization could only be accounted for by having a much higher conversion ratio than the conventional one.

Supporters of the overproduction theory have had to take recourse to the fat-to-sugar notion in order to account for the large amounts of sugar excreted in the urine of the fasting diabetic in addition to that utilized by his tissues. They have postulated this conversion since they cannot understand how a sufficiently large amount of sugar can come from the protein catabolized to account for the sugar burned plus that which is excreted. We have shown here that conversion of protein to sugar can account for this when one revises the $D: N$ ratio to a higher value and keeps a strict accounting of the amounts involved.

The facts presented in this paper help in giving a satisfactory explanation of the disturbance of carbohydrate metabolism in diabetes. The trouble in diabetes cannot be accounted for by an inability of the tissues to oxidize any glucose; they do utilize definite amounts of this foodstuff (17). The chief fault, as far as carbohydrate metabolism is concerned, appears to be that the body cannot dispose of surplus glucose by changing it to glycogen, fat and other possible glucose derivatives. The amount of glucose oxidized directly by the tissues in the fasting diabetic can be adequately supplied by conversion from body protein, even though considerable amounts of glucose are being excreted in the urine. In this way those wellestablished facts concerning carbohydrate metabolism in diabetes can be accounted for without having recourse to a conjectural hypothesis involving the conversion of fat to sugar.

\section{SUM MARY}

For the classical $\mathrm{D}: \mathrm{N}$ ratio of 3.65 or $\mathrm{D}:$ Protein ratio of 0.58 in the phlorhizinized fasting dog, we must consider the urinary sugar as but part of the total sugar produced from the protein represented by the nitrogen of the urine. The other portion of this sugar is used by the tissues of the animal. On feeding the animal protein, there is a definite increase in this tissue utilization so that the urinary $D: N$ ratio actually decreases.

The depancreatized dog does not show such a marked increase in glucose tissue utilization on feeding. In this preparation one can estimate the extra sugar resulting from fed protein since the amount used by the tissues is small and is easily corrected for. When this correction is applied the $\mathrm{D}: \mathrm{N}$ ratio is between 5 and 6 and then the $\mathrm{D}$ : Protein ratio approaches 1 .

With this higher $D: N$ ratio we can account for both the glucose excreted in the urine and that used by the tissues in fasting diabetics as coming from body protein and it is unnecessary to invoke the aid of the questionable notion of conversion of fat-to-glucose.

\section{BIBLIOGRAPHY}

1. MacLeod, J. J. R., Der Brennstoff des Lebens. Ergebn. d. Physiol., 1930, 30, 408.

Idem, Diabetes as a physiological problem. Lancet, 1930, 2, 383.

2. Reviewed in Joslin, E. P., Treatment of Diabetes. Lea and Febiger, Philadelphia, 1937, 6th Ed.

3. Lusk, G., The Science of Nutrition. W. B. Saunders, Philadelphia, 1928, 4th Ed.

4. Reilly, F. J., Nolan, F. W., and Lusk, G., Phlorhizin diabetes in dogs. Am. J. Physiol., 1898, 1, 395.

5. Deuel, H. J., Jr., Wilson, H. E. C., and Milhorat, A. T., Animal calorimetry; mechanism. The action of phlorhizin diabetes. J. Biol. Chem., 1927, 74, 265.

6. Wierzuchowski, M., Intermediary carbohydrate metabolism; ketosis in phlorhizin diabetes. J. Biol. Chem., 1927, 73, 417.

7. Janney, M. W., and Blatherwick, N. R., Glucose formation from human proteins. J. Biol. Chem., 1915, 23, 77.

8. Gray, J. S., Ivy, A. C., and Cuthbert, F. P., The conversion of protein to glucose in depancreatized and phlorhizinized dogs. J. Biol. Chem., 1939, 128, 173.

9. Bollman, J. L., Mann, F. C., and Magath, T. B., Studies on physiology of liver; effect of total removal of the liver on deaminization. Am. J. Physiol., 1926, 78, 258. 
10. Drury, D. R., Bergman, H. C., and Greeley, P. O., The glucose utilization of phlorhizinized dogs after hepatectomy. Am. J. Physiol., 1936, 117, 323.

11. Bergman, H. C., and Drury, D. R., Effect of feeding and fasting on sugar utilization of eviscerated rabbits. Proc. Soc. Exper. Biol. and Med., 1937, 37, 414.

12. Hofmeister, F., Ueber Resorption und Assimilation der Nahrstoffe. Arch. f. exper. Path. u. Pharmakol., 1889, 26, 355.

13. Chambers, W. H., Undernutrition and carbohydrate metabolism. Physiol. Rev., 1938, 18, 248.

14. Himwich, H. E., and Nahum, L. H., The respiratory quotient of the brain. Am. J. Physiol., 1932, 101, 446.

15. Yater, W. M., Markowitz, J., and Cahoon, R. F., Consumption of blood sugar by muscle in the nondiabetic and in the diabetic state. Arch. Int. Med., 1933, 51, 800.

16. Lusk, G., The Science of Nutrition, W. B. Saunders, Philadelphia, 1928, 4th Ed., p. 79. 17a. Greeley, P. O., and Drury, D. R., The glucose utilization of hepatectomized diabetic rabbits. Am. J. Physiol., 1940, 130, 249.

b. Mann, F. C., and Magath, T. B., The effect of total removal of the liver after pancreatectomy on the blood sugar level. Arch. Int. Med., 1923, 31, 797.

18. Soskin, S., The utilization of carbohydrate by totally depancreatized dogs receiving no insulin. J. Nutrition, 1930, 3, 99.

19. Voit, E., Quoted by Lusk. The Science of Nutrition, W. B. Saunders, Philadelphia, 1928, 4th Ed., p. 108.

20. Benedict, F. G., A study of prolonged fasting. Carnegie Institution of Washington Pub. 203, 1915.

21. Von Falkenhausen, M., Untersuchungen uber den Eiweissstoff wechsel beim experimentellen Pankreasdiabetes. Arch. f. exper. Path. u. Pharmakol., 1925, 109, 249.

22. Geyelin, H. B., and Dubois, E. F., A study of blood, urine and respiratory metabolism. J. A. M. A., 1916, 66, 1532. 